\title{
MODIFYING BSC FOR NATIONAL NANOTECHNOLOGY DEVELOPMENT: AN IMPLICATION FOR "SOCIAL CAPITAL" ROLE IN NIS THEORY
}

\author{
Sepehr Ghazinoory ${ }^{1}$, Abdol Soofi ${ }^{2}$ \\ ${ }^{1}$ Department of Information Technology Management, Tarbiat Modares University, \\ Ale-Ahmad St., Tehran, Iran \\ ${ }^{2}$ University of Wisconsin-Platteville, 1 University Plaza, Platteville, WI, 53818, USA \\ E-mails: ${ }^{1}$ ghazinoory@modares.ac.ir (correspondingauthor); ${ }^{2}$ soofi@uwplatt.edu
}

Received 13 March 2011; accepted 18 November 2011

\begin{abstract}
In this research, we have designed and implemented the Strategy Map and Balanced Scorecard technique in evaluating the progress of National Iranian Nanotechnology Initiative (NINI). In conducting this research, we have learned that the layers of Strategy Map are congruent with the National Innovation System (NIS) levels. The use of Strategy Map and Balanced Scorecard in conjunction with an opinion survey of the nanotechnology experts showed "social capital" at the bottom layer and economic development at the top layer of the Strategy Map of the NIS infrastructure in Iran. These findings have broad implications not only for Iranian nanotechnology development, but also are important for the theory of NIS.
\end{abstract}

Keywords: National Innovation System, social capital, Balanced Scorecard, Strategy Map, National Iranian Nanotechnology Initiative.

Reference to this paper should be made as follows: Ghazinoory, S.; Soofi, A. 2012. Modifying BSC for national nanotechnology development: an implication for "social capital" role in NIS theory, Technological and Economic Development of Economy 18(3): 487-503.

JEL Classification: A13, E24, E61, 031.

\section{Introduction}

It is well known that a strategy by itself does not bring any meaningful changes in an organization. The desirable changes in an organization happen due to successful implementation of the strategies. Failure of management in implementing the adopted strategies is often the cause of the failure of management in achieving the corporate goals. 
Several studies have identified cause(s) of the failures of strategies (Keshavjee et al. 2009; Watts, Segal 2009). From a systemic standpoint, the main reason for this problem is the gap between strategic operating layers in organizations where operations and daily decisions follow different processes. In order to solve these problems, Balanced Scorecard (BSC) (Kaplan, Norton 1992) and Strategy Map (Kaplan, Norton 2004) were introduced and have been extensively used in business environment ${ }^{1}$.

According to BSC, successful implementation of strategic goals requires translation of the goals into measures of performance. These financial and nonfinancial metrics are indicators of the degree of success in the implementation of the strategic goals by the organizations.

It turns out that the observed challenges in the implementation of the strategies at the firm level are present in implementation of strategies at the national level also. However, hitherto, the use of BSC and Strategy Map in resolving the issues of strategy implementation has been confined to business enterprises only.

This paper presents a modified Balanced Scorecard and Strategy Map for development of strategies for state owned enterprises by developing and implementing the strategy for National Iranian Nanotechnology Initiative (NINI). Furthermore, for modeling this new concept, National Innovation System (NIS) approach and Balanced Scorecard (BSC) were integrated, a survey of expert opinion were conducted, and statistical significance tests of the survey responses were performed. The tests determined the statistical significance of the scales of the questionnaire, particularly the place and role of the concept of social capital in this model that reflects the importance of this scale.

The structure of the paper is as follows. In section 2 research literature is reviewed and the essential concepts that appear in the literature are presented. A conceptual model of BSC and NIS combination is presented in section 3. In section 4 a model for National Iranian Nanotechnology Initiative (NINI) that is based on opinions of the Iranian nanotechnology experts is presented and statistically tested. Sections 5 and 6 present the discussion and conclusions of the study, respectively.

\section{Literature review}

\subsection{Balanced Scorecard}

In 1992, Robert Kaplan and David Norton introduced a new approach for business function measurement, named Balanced Scorecard (Kaplan, Norton 1992). Balanced Scoreboard (BSC) is an important technique for developing and implementing organizational strategy.

Balanced Scorecard expresses the strategy of dividing an organization into measureable categories and distributes the pivotal organizational functions into balanced categories. The categories comprise 4 perspectives:

1. Financial perspective.

2. Customer perspective.

3. Internal business process perspective.

4. Learning \& growth perspective.

1 BSC can be composed with other tools of strategic planning, such as SWOT (Ghazinoory et al. 2011) 
Originally, Balanced Scorecard assessment was conceived as a function evaluator; however, it was transformed into a strong tool for strategy evaluation, and now it is known as a "strategic management system" by Kaplan and Norton (2001).

Balanced Scorecard is a group of criteria that gives the managers a rapid but comprehensive vision of their business. This management tool is very popular among business executives and is extensively used in the making of managerial decisions. According to a survey of the top business executives conducted around the globe, 71\% of Asian, 63\% of European, $62 \%$ of North American, and $60 \%$ of Latin American executives have used Balanced Scorecard as a business decision-making tool (Rigby, Bilodeau 2007).

\subsection{Strategy Map}

The visual representation of the elements of the four-perspective strategy model that could form the basis for discussions among the executives is called Strategy Map. The executives could use the visual map as a framework to discuss the direction of the movements and the priorities of the enterprise (Kaplan, Norton 2004).

Balanced Scorecard alters strategic map to criteria and goals, and the goals should be considered as the essential strategic measures for each criterion in Balanced Scorecard. Typically, the objectives in the four perspectives of a Strategy Map lead to about twenty to thirty measures being required in the associated Balanced Scorecard.

\subsection{Strategy Map and BSC in governmental and non-profit organizations}

Strategies of government agencies and programs are significantly different from strategies of non-governmental organizations. Most non-profit and government organizations have difficulties in using the original architecture of the Balanced Scorecard, which places the financial perspective at the top of the hierarchy. Since profitability or increasing market share is not the primary objective for most of the governmental organizations, the architecture can be rearranged to place satisfaction of customers of the government organizations or the goodwill of the constituents at the top of the hierarchy (Banker et al. 2011).

Examples of governmental national strategies, which could be traced by modified Strategy Map are national technology strategies, are discussed in the next sections.

\subsection{Application of BSC in developing technology strategy}

Mikalsen (2003) used Balanced Scorecard for development of technology strategy in Seagull Company. However, he did not change Kaplan BSC, nor did he explain the reason(s) why a business strategy is immediately applicable for technology strategy.

According to Durrani et al. (2000), Kaplan and Norton Scorecard are not appropriate for the development of technology strategy, because BSC does not involve any independent perspective for the technology. They presented a new analytical framework with categories and relationships that is presented in the flow diagram of Fig. 1. Durrani et al. (2000) applied this model in developing corporate strategy for Psion Company, but they did not explain the 
reason(s) for the proposed changes. However, this model satisfies Loch expectations because by replacing technology and production perspectives for the internal business processes as well as for the learning and growth perspectives, it is possible to discuss the questions raised in technology strategy. The Durrani's model allows discussions of the questions such as technology evolution, technology selection, determination of substantial technologies, quality of production, etc. in the context of technology perspective. The model enables the analyst to avoid dealing with the technological issues in the framework of internal business processes and learning, as well as growth perspectives.

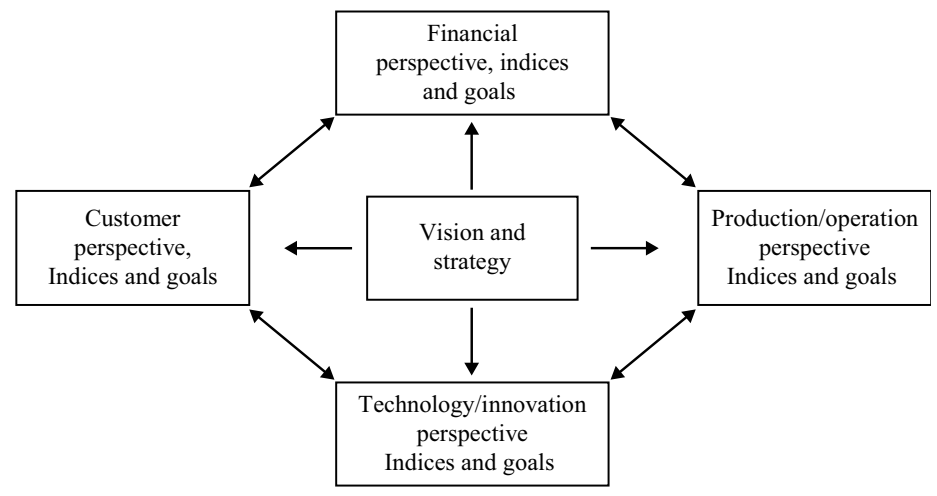

Fig. 1. Balanced assessment model for technology strategy (Durrani et al. 2000)

As can be seen, Durrani uses BSC for technology strategy development and innovation planning at the firm level. However, it appears that the most useful application of BSC for developing the strategies of national innovation is combining it with the theory of National Innovation System, even though, hitherto, no one has used it for innovation strategy development at the national level.

\subsection{National Innovation System}

The adaptation of BSC was originally designed for development of strategy for business organizations. Using the BSC for development of strategy for governmental organizations requires a discussion of the National Innovation System (NIS). Accordingly, after a brief discussion of NIS in this section, we discuss National Iranian Nanotechnology Initiative (NINI) as a model of planning for development of an emerging technology at the national level in section 2-6 below ${ }^{2}$.

Nowadays technology development requires a system commonly known as National Innovation System (NIS), without which achieving major goals of technology development, i.e. social welfare and economic development is impossible. Thus, success of national technology strategy is more likely when a systematic approach in presenting the Strategy Map is used. In the next section, we will briefly discuss a combination of NIS and Strategy Map.

2 For a discussion of Iranian NIS, see Ghazinoory and Ghazinoori, 2006. 
The term National Innovation System was used initially by Freeman in 1987 study about technology development in Japan, where he defined NIS as "the network of institutions in the public and private sectors whose activities and interactions imitate, import, modify and diffuse new technologies" (Freeman 1987: 1).

Lundvall (1992) differentiated between the broad and narrow definitions of NIS. In the narrow definition, NIS comprises organizations and institutes such as R\&D units, technology institutes, and universities that engage with research and exploration activities, while in the broad definition, NIS consists of elements and relations that interact in production, diffusion, and use of new profitable knowledge.

Based on OECD (1999), NIS has seven functions, and active organizations in these functions and their activities are shown in Table 1.

Table 1. NIS functions and activities

\begin{tabular}{|c|c|c|}
\hline Layer & Function & Activities \\
\hline 1 & Policymaking & $\begin{array}{l}\text { - Technology and innovation policy } \\
\text { - Leading and determination of general framework } \\
\text { - Coordination, supervision and assessment }\end{array}$ \\
\hline 2 & Performing R\&D & $\begin{array}{l}\text { - Basic research } \\
\text { - Applied research } \\
\text { - Developmental research } \\
\text { - Reverse engineering }\end{array}$ \\
\hline 3 & $\begin{array}{l}\text { Research \& } \\
\text { innovation } \\
\text { facilitating }\end{array}$ & $\begin{array}{l}\text { - Support by investment and provision of financial resources } \\
\text { - Support of standard-setting } \\
\text { - Support of intellectual property }\end{array}$ \\
\hline 4 & $\begin{array}{l}\text { Human resource } \\
\text { development }\end{array}$ & $\begin{array}{l}\text { - Training, developing and promoting } \\
\text { - Facilitating the mobility of human resources }\end{array}$ \\
\hline 5 & $\begin{array}{l}\text { Technology } \\
\text { diffusion }\end{array}$ & $\begin{array}{l}\text { - Informing and technology presentation } \\
\text { - Search and information referencing services } \\
\text { - Training, consultation and technical services } \\
\text { - Joint research and technology projects } \\
\text { - Government procurement } \\
\text { - Technology transfer } \\
\text { - Local or industrial networking }\end{array}$ \\
\hline 6 & $\begin{array}{l}\text { Promotion of } \\
\text { technological } \\
\text { entrepreneurship }\end{array}$ & $\begin{array}{l}\text { - Funding technology-based firms } \\
\text { - Administrative and managerial supporting of entrepreneurs } \\
\text { and start-up companies }\end{array}$ \\
\hline 7 & $\begin{array}{l}\text { Goods \& services } \\
\text { production }\end{array}$ & $\begin{array}{l}\text { - Production, supply and exports of goods } \\
\text { - Production and supplying services }\end{array}$ \\
\hline
\end{tabular}

\subsection{National Iranian Nanotechnology Initiative (NINI) ${ }^{3}$}

The development of nanotechnology in Iran began in 2001 when the former president of Iran, Mr. Mohammad Khatami, received a letter from the Iranian scientist in the United States, in which the importance of nanotechnology was highlighted. At that time, Iran was seeking technology focus areas with high economic potential to be used as the bases for further industrial

3 See Ghazinoory et al. (2009a) for a detailed discussion of NINI. 
development of the country. The letter was considered by the Technology Cooperation Office $(\mathrm{TCO})^{4}$, which is under direct supervision of the presidency and is responsible for technology development in the country. TCO decided to pursue the development of nanotechnology due to: (i) its significant impact on people's quality of life, (ii) its huge demand in the future, and (iii) the fact that Iran was not far behind pioneer countries in the field at that time, and the belief that, with high likelihood, the country could catch-up with them.

TCO created a committee to carry out studies for nanotechnology development policies. After initial studies and promotion of nanotechnology among specialists and experts, the committee recommended the creation of a council responsible for the development of nanotechnology in the country. In 2003, Iran Nanotechnology Initiative Council (INIC) was established and subsequently the ten year strategic plan of nanotechnology development as NINI (National Iranian Nanotechnology Initiative) ${ }^{5}$ was approved by the cabinet in July 2005 (Ghazinoory, Ghazinouri 2009). According to the vision of the program, nanotechnology should be used for the creation of wealth and improvement of people's quality of life, and achieving a proper position among 15 countries advanced in nanotechnology in the world by 2015. INIC is in charge of coordinating nanotechnology development activities of other governmental institutions, setting nanotechnology as a priority in these entities, mobilizing their financial and human resources for the development of this technology, and reaching goals of the future strategy.

Since 2001, TCO's most important activities in nanotechnology development consisted of the following:

1. Creating a network among country's laboratories that have useable instruments;

2. Recognizing Iranian scientists who are active in nanotechnology and supporting their activities;

3. Providing financial incentives to Iranian scientists to publish nanotechnology articles in international scientific journals;

4. Finding international partners for research and scientific collaborations;

5. Publicizing advances in nanotechnology in Iran and other countries;

6. Offering of advanced courses in nanotechnology at the MSc and $\mathrm{PhD}$ programs throughout the Iranian universities.

Development of nanotechnology in Iran is the first emerging technology in that country that was based on a systematic national planning and did not evolve on the ad-hoc planning base (Ghazinoory et al. 2009b). Thus, measuring the efficiency and efficacy of National Iranian Nanotechnology Initiative (NINI) is imperative. For this reason, Balanced Scorecard and Strategy Map were used in the initiative and in the present paper.

\subsection{Reasons of BSC modifications as a research shortcoming}

As it was described above, BSC is an important tool for implementation of the strategy; however, this tool is rarely used in technology strategy planning. Furthermore, to make the tool adaptable for this purpose BSC must be modified (see Fig. 1). Naturally, using BSC in

\footnotetext{
Recently TCO has been renamed to The Cenr for Innovation and Technology Cooperation (CITC)

5 http://en.nano.ir/files/futurestrategy_2006_2015.pdf
} 
new applications requires many modifications of the score board method. For example, if we choose to use BSC for National Innovation System of nanotechnology in an emerging economy like Iran, one must consider that numerous cultural, sociological and economic issues that present themselves, issues which do not appear in applications of BSC at the firm level might appear. More specifically, nanotechnology like many other emerging technologies, like information technology faces a great deal of resistance in a traditional society like Iran where centers of support and promotion for such technologies have not been created.

Therefore, it is essential that these problems are considered in modifying the BSC for use in nanotechnology, a subject we will deal with in the next section.

\section{Modeling}

In achieving the research goals of measuring the efficiency and efficacy of NINI, the following algorithm was designed:

\subsection{Modifying 4 perspectives of BSC regarding national technology strategy specifications}

As mentioned in previous studies (see section 2-4), application of BSC and Strategy Map for developing technology strategy needs the modification of the four perspectives of BSC. As considered in section 2-3, modification of these methods for use in governmental organizations and programs should be justified. Thus, we modified, with justification, the four aspects of the model according to the specifications of national technology strategy system and within the frameworks of the guideline set by the prior studies, as shown in Table 2 . These modifications were based on interviews with experts and strategists.

The original and modified perspectives of BSC are shown in Table 2 below.

Table 2. Four modified perspectives of BSC for national technology strategy

\begin{tabular}{ll}
\hline \multicolumn{1}{c}{ Original BSC perspectives } & $\begin{array}{c}\text { Modified BSC perspectives } \\
\text { (according to national technology strategy) }\end{array}$ \\
\hline Financial perspective & Macroeconomic perspective \\
\hline Customer perspective & Market and Trade perspective \\
\hline Internal processes perspective & Institutional and Administrative perspective \\
\hline Learning and Growth perspective & Human Resource perspective \\
\hline
\end{tabular}

\subsection{Defining BSC criteria using NIS approach}

Formulation of Strategy Map and BSC requires definition of the criteria of each perspective. Generally, in an organizational context, managers define related criteria, but here we needed a known theory, that is, the theory of national system of innovation, that could ensure inclusion and consideration of all required activities and infrastructures for technology development at the national level. For this purpose, NIS approach, as described in section 2-5, was applied. Matching NIS levels with BSC perspectives results are the following: 


\subsubsection{Human resource perspective}

This perspective was considered to be identical to human resource development function in NIS (see $4^{\text {th }}$ layer of Table 1 ).

\subsubsection{Administrative and institutional perspective}

In this perspective, there are four different functions of NIS:

- Policymaking (First layer of Table 1).

- Research \& innovation facilitating (Third layer of Table 1).

- Promotion of technologic entrepreneurship (Sixth layer of Table 1).

- Performing R\&D (Second layer of Table 1).

\subsubsection{Market and trade perspective}

Because this perspective includes two categories (technology trade and products, and services trade), two functions are presented:

- Technology diffusion (Fifth layer of Table 1).

- Goods and services production (Seventh layer of Table 1).

\subsubsection{Macroeconomic perspective}

This perspective is not a component of NIS, but it is the outcome of NIS; however, we consider the criteria that present a role for technology in the national economic development here. These criteria include R\&D expenditure as a percentage of the GDP, and the extent of use of nanotechnology in production of goods and services in the national production.

\subsection{Social capital issue}

Please note that, despite of NIS' focus on importance of soft categories such as norms, habits and beliefs, these topics that are cumulatively referred to as social capital are not directly included in discussions of the National Innovation Systems. However, Arundel (2003) mentioned the importance of thrust index in assessment of European system of innovation, with "trust" being one of the major elements of social capital. Other works involving the use of the concept of social capital in innovation studies consist of the following. Dakhli and deClercq (2004), using data from the World Values Survey, has provided 'partial' statistical support for the finding that two of the three components of the social capital, i.e. trust and associational activity ${ }^{6}$, have positive effect on innovation. Moreover, Fairchild (2002) in discussing knowledge management with the use of BSC includes concepts such as culture, custom, values and skills as the constituent parts of knowledge. Kaasa (2009) refers to the sum of networks, trust, norms, as social capital and considers it "a relevant innovative activity". Finally, Kaasa (2009) defines the aggregate social capital as the sum of individual social capital of all persons who are involved in innovative activities, and constructs six factors of social capital using factor analysis. Furthermore, Kaasa (2009) measures the effect of these factors

6 The third component is norms of civic behavior. 
on the innovative activities at the regional level in Europe, and concludes that social capital plays a significant role in innovation activities of the studied countries. Jamali et al. (2011) and also Molina-Morales, Martínez-Fernández (2010) confirmed the role of social capital in partnerships and networks on the innovation performance. Adam (2011) investigated the such impact in regional innovation systems.

Based on these empirical findings and the use of the concept of social capital in prior BSC studies of the innovation activities, we include social capital as an element of human resource perspective in this research. Moreover, it should be noted with emphasis that statistical test of the data accumulated by an opinion survey of Iranian experts in nanotechnology identifies social capital as a fundamental determining factor for the nanotechnology strategy map (see Fig. 3).

This means that, in addition to the already accepted layers of NIS (7 layers that appear in Table 1), another layer with the name of social capital must be added to the NIS, without it the wheel of innovation would be incomplete.

One may view the social capital as the very foundation of NIS for any country. In Fig. 2 it is showed that the social capital layer forms the very ground floor of the structure of national system of innovation as well as the economy of any country.

What is "social capital"?

There are various definitions for "social capital". For example, Fukuyama (1999) defined social capital as "... collection of existing norms in social systems that promote cooperation level in society members and decreases cost of communication and exchanges". On the basis of this definition, concepts such as civil society and social institutions possess a close conceptual relation with social capital.

"Social capital refers to the institutions, relationships, and norms that shape the quality and quantity of a society's social interactions" (The World Bank Group 1999). Evidence, mostly gathered by World Bank's studies, indicates that social cohesion is a crucial element for sustainable economic development.

A third definition provided by Putnam (2000), seems to be a more representative, typical way of defining social capital, and is used in the present study. According to Putnam social capital is:

"...features of social life - networks, norms, and trust - that enable participants to act together more effectively to pursue shared objectives... Social capital, in short, refers to social connections and the attendant norms and trust" (Putnam 2000).

We adopt Putnam's definition of social capital in the present study. In the process of modification of the perspectives of the original BSC, we conducted an opinion survey of the Iranian nanotechnology experts (see the discussion of opinion survey below). In the survey questionnaire, we sought the views of respondents about the presence and strength of social capital by asking them about the importance the roles "trust", "networks", and "norms' play in socio-economic interactions. The results are summarized and presented as the arrows connecting the bottom (social capital) layer and the Human Resource Development layer. We present the preliminary framework of a national technology strategy in Fig. 2.

Soofi and Ghazinoory (2011) confirmed the weakness of cooperation innovation networks in Iran. 


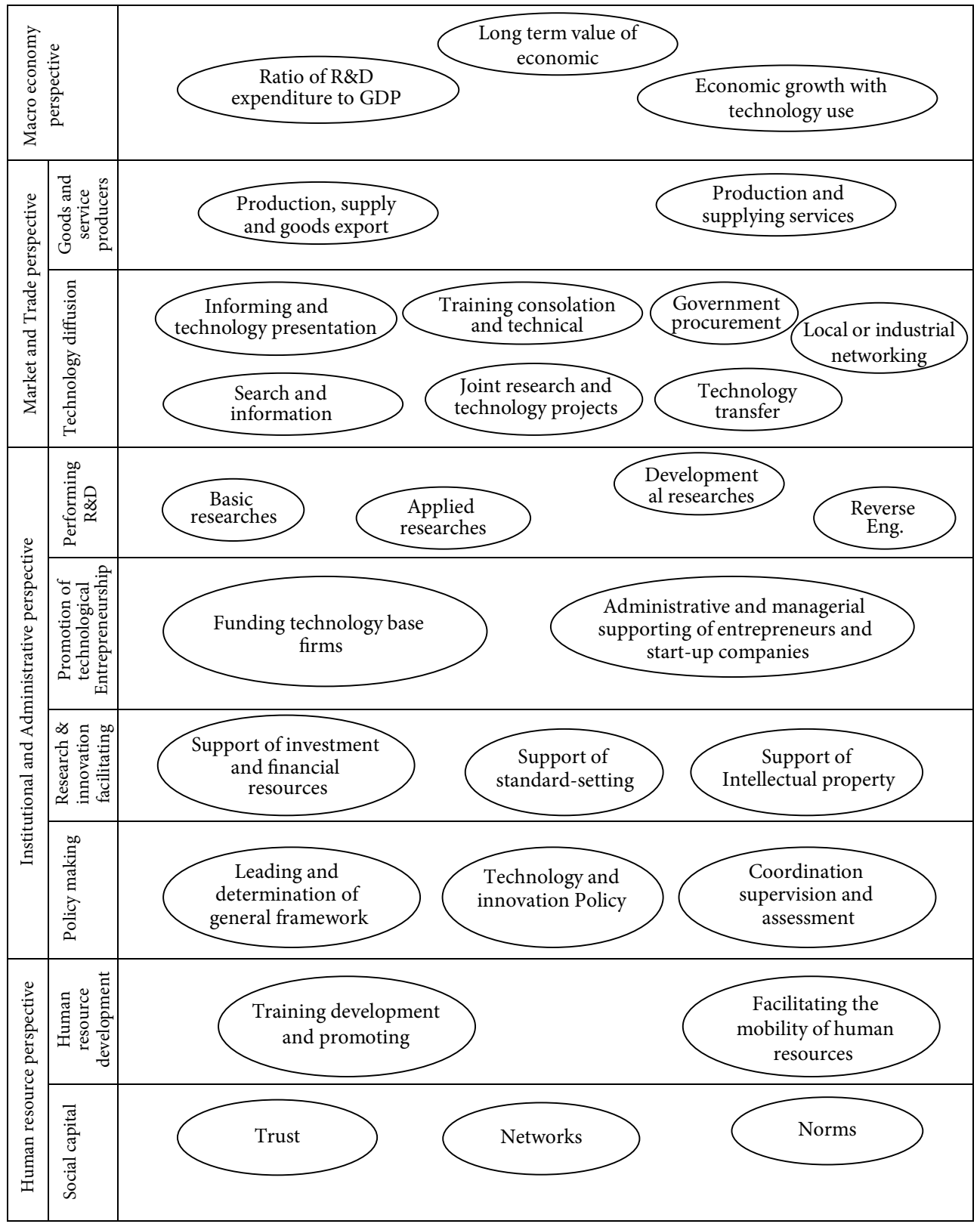

Fig. 2. Initial framework for national technology Strategy Map (our compilation) 


\section{Opinion survey}

As was discussed in section 2-2, in preparation of strategic plan one should account for the interactions at two levels: first, interaction among the variables that are at the same level, and second, interactions between the variables at the lower and higher levels (see Fig. 2 for the layers).

For this reason, we must determine the relationships, if any, between the elements in Fig. 2, are statistically significant. We used a 5-item Likert scale survey questionnaire to gather data in identifying statistically significant relationships. For example, in general, we asked: "To what extent does variable A is related to variable B in nanotechnology?" Specifically, as an example of the questions in the questionnaire, we cite "What is the relation between the public trust and human resource training?"

The questionnaire consisted of 126 questions that appeared in 10 measurement scales. The names of these scales and the number of questions for each scale in the questionnaire appear in Table 4 below. The scale consists of social capital, human capital, policymaking, promotion of research and innovation, promotion of technological entrepreneurship, knowledge capacity building, technology diffusion, production of goods and services, macro-economy, and relationship between the layers.

The population of the study consisted of 27 respondents $^{8}$, practically all of the scientific, technical, and engineering members of research teams working on nanotechnology projects at the time (The characteristics of these respondents appear in Table 3). Personal interviews were conducted during spring 2008. We used student t-distribution with 26 -degree of freedom in hypothesis testing. We also used SPSS package in the statistical analyses.

Table 3. Characteristics of the respondents

\begin{tabular}{lll}
\hline \multicolumn{1}{c}{ Work experience } & \multicolumn{1}{c}{ Major field of study } & \multicolumn{1}{c}{ Level of education } \\
\hline & IT 1 person & Bachelor Degree: 1 person \\
Less than 5 year: 8 persons & MBA 3 persons & Master Degree; 21 persons \\
6 to 10 years: 11 persons & Executive management 3 persons & Doctorate: 3 persons \\
11 to 15 years: 1 person & Economics 2 persons & No Response; 2 persons \\
More than 15 years: & Biotechnology 1 person & \\
2 persons & Management of Technology 12 persons & \\
No response: 5 persons & Industrial management 1 person & \\
& Financial management 2 persons & \\
& Industrial Eng. 1 person & Total: 27 persons \\
\hline Total: 27 persons & Chemical Eng. 1 person & \\
\hline
\end{tabular}

\footnotetext{
The authors agree with a constraint that the number of the respondents may be inadequate from the sampling theory perspective. However, the respondents in the present study constituted the entire workforce who was active in nanotechnology field at the time in Iran, and who were knowledgeable about the concepts of strategy and national system of innovation. Moreover, the authors acknowledge that drawing inference from the sample observation and generalizing the notion that social capital forms the foundation of any NIS requires a sample consisting of experts from many countries. We plan to conduct such a survey in future.
} 
We used the mean value of 5 -item Likert scale $(\mu=3)$ and the standard deviation of the scale as population parameters in calculation of the t-statistics. We tested the following two-tailed hypotheses:

$$
\begin{aligned}
& H_{0}: \mu=3, \\
& H_{a}: \mu \neq 3 .
\end{aligned}
$$

We observe statistically significant test results for 70 out of 126 questions. This implies that there are only 70 statistically significant relationships between the factors of Fig. 2 . These relationships are presented in the final Strategy Map in Fig. 3.

For studying the reliability of answers, we used Cronbach's a (alpha) statistic. It is commonly used as a measure of the internal consistency reliability of a psychometric instrument. Cronbach's alpha will generally increase when the correlations between the items increase. For this reason, the coefficient is also called the internal consistency or the internal consistency reliability of the test. Cronbach's alpha measures how well a set of items (or variables) measures a single uni-dimensional latent construct. When data have a multidimensional structure, Cronbach's alpha will usually be low. We used the following formula for that concept:

$$
r_{\alpha}=\frac{J}{J-1}\left(1-\frac{\sum_{j}^{n} S_{j}^{2}}{S^{2}}\right) 0 \leq r_{\alpha} \leq 1,
$$

where $J$ is the number of questions in the instrument, $S^{2}$ is variance of the questionnaire, and $S_{j}^{2}$ is the variance for each question.

Note that an alpha value close to zero implies a low reliability of the instrument. An alpha value close to unity implies high reliability of the instrument.

Table 4 shows the Cronbach's alpha results for the survey instrument used in this study.

The Cronbach's alphas in the table point to the strong reliability of the instrument in all but two categories: Production of goods and services and Macroeconomy. The low alpha values might be due to the small number of questions in these two scales.

Table 4. Cronbach's alpha as a measure of reliability of survey instrument

\begin{tabular}{lcc}
\hline \multicolumn{1}{c}{ Name of the scale } & Number of questions & Value of Cronbach's alpha \\
\hline Social capital factors & 6 & 0.8108 \\
\hline Human Capital factors & 10 & 0.7235 \\
\hline Policymaking factors & 13 & 0.7195 \\
\hline Research \& innovation facilitating factors & 12 & .8451 \\
\hline Promotion of technologic entrepreneurship factors & 22 & 0.8669 \\
\hline Knowledge Capacity Building & 21 & 0.6672 \\
\hline Technology diffusion & 23 & 0.7779 \\
\hline Production of Goods and service & 4 & 0.5652 \\
\hline Macroeconomy & 3 & 0.4627 \\
\hline Relation between areas & 12 & 0.8742 \\
\hline Total & 126 & 0.8754 \\
\hline
\end{tabular}




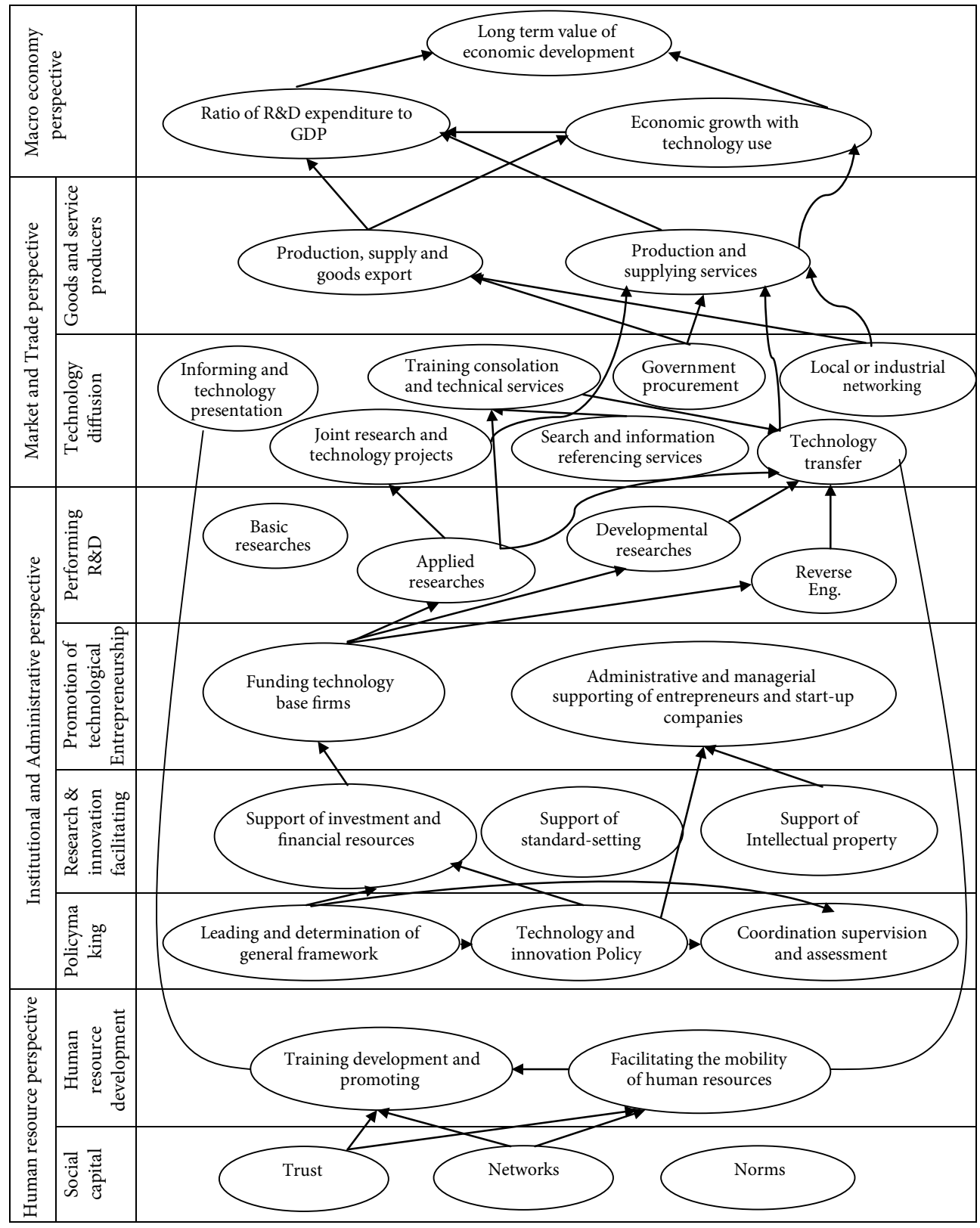

Fig. 3. Effective relations between criteria in technology Strategy Map (our compilation) 


\section{Discussions}

This study makes two important contributions to the literature on National Innovation System and technology strategy formulation. First, for the first time, we have empirically determined that social capital 'enters the very ground floor', to use Schumpeter's phraseology, of National Innovation System. Second, we have demonstrated that the analytical tools of scorecard board and strategy maps have important roles to play in developing National Innovation System.

We note that the topic of the societal impact of nanotechnology is not a new one, Ghazinoory and Heydari (2008), and Sheetz et al. (2005) have dealt with this topic. Even the governance of nanotechnology to mitigate the adverse effects of nanotechnology on society has been studied (Whitman 2007). What is new, however, is the effect of society and culture on development of nanotechnology, the subject we have studied here.

\section{Conclusions}

After reviewing the literature on corporate strategy formulation and implementation, we discussed the idea that the analytical tools of scorecard board and Strategy Map must be modified for use in development and implementation of strategies for governmental and notfor-profit organizations. We applied the modified analytical tools in evaluating the outcome of National Iranian Nanotechnology Initiative (NINI). Next, we discussed the results of a survey questionnaire that were completed by Iranian experts on nanotechnology, statistically verified the internal validity and reliability of the survey questionnaire, and using t-statistics tested the statistical significance of the mean value of responses to 126 questions in the questionnaire. The test results show interrelationship among the variables in different layers of the NIS, as the layers are defined by OECD (1999). We found illuminating, interesting results which are discussed next.

For the first time, the location of social capital as a layer in NIS was empirically determined. According to Fig. 3, there are 9 layers with social capital forming the foundation of the structure of the NIS. 7 layers of NIS are arranged according to schema proposed by OECD (1999). Moreover, macroeconomic category appears as the top layer. The arrangement of the layers in NIS suggests that social capital layer forms the foundation of the NIS and NIS forms the basis of the macro economy. These fundamental concepts, which are based on responses of the limited number of nanotechnology experts, are the most important contributions of this paper. We believe this is a significant contribution, even though its generality maybe constrained by the limited number of observations they are based on. Additional studies, based on larger sample sizes should be conducted in order for one to draw safer inferences about the general validity of the results.

We note that the methodology of this paper is readily applicable in other economies. We hope that other researchers use the approach presented in the present paper in surveys of the expert opinions of larger samples in other countries. The empirical verification of the findings from surveys of larger sample sizes in other countries may validate the findings in the present study. 
In addition, in this study, we demonstrated that the analytical tools for corporate strategy development and outcome measurement of Scorecard Board and Strategy Map have important role in development of National Innovation Systems.

Finally, Fig. 3 can illustrate a suitable picture of hierarchical progression of a national technology strategy. The systematic representation of the hierarchy of technological progression allows identification of the stages of technological development of a country. In the case of technological progression of nanotechnology in Iran, one could reasonably attest to full, satisfactory development of the technological system at the lower layers, such as human resource training, and policymaking. However, the progresses of the higher layers tend to be rather limited. This result could be due to the required time before yields on nanotechnology investment. In short, at the time of conduct of the survey, the use of nanotechnology in production of goods and services was minimal. Nevertheless, given the short span of time since the advent of nanotechnology development in the country, it is too early to measure the contributions of this emerging technology to economic growth in Iran.

\section{References}

Adam, F. 2011. Regional innovation performance in light of social-capital research and application, Social Science Information 50: 414-428. http://dx.doi.org/10.1177/0539018411411022

Arundel, A. 2003. European Innovation Scoreboard: Technical Paper No 5 National Innovation System Indicators.

Banker, R.; Chang, H.; Pizzini, M. 2011. The judgmental effects of strategy maps in balanced scorecard performance evaluations, International Journal of Accounting Information Systems 12: 259-279. http://dx.doi.org/10.1016/j.accinf.2011.08.001

Dakhli, M.; deClercq, D. 2004. Human capital, social capital, and innovation: amulti-country study, Entrepreneurship \& Regional Development 16: 107-128. http://dx.doi.org/10.1080/08985620410001677835

Durrani, T. S.; Forbes, S. M.; Carrie, A. S. 2000. Extending the balanced scorecard for technology strategy development, in Proc. IEEE IEMC'99, 142-147.

Fairchild, A. M. 2002. Knowledge management metrics via a balanced scorecard methodology, in Proceedings of the 35th Hawaii International Conference on System Sciences. http://dx.doi.org/10.1109/HICSS.2002.994356

Freeman, C. 1987. Technology Policy and Economic Performance: Lessons from Japan. Printer. London.

Fukuyama, F. 1999. Social Capital and Civil Society, in Conference on second generation reform.

Ghazinoory, S.; Abdi, M.; Azadegan-Mehr, M. 2011. SWOT methodology: astate-of-the-art review for the past, a framework for the future, Journal of Business Economics and Management 12(1): 24-48. http://dx.doi.org/10.3846/16111699.2011.555358

Ghazinoory, S.; Divsalar, A.; Soofi, A. 2009b. A new definition and framework for the development of a national technology strategy: the case of nanotechnology for Iran, Technol. Forecast. Soc. Change 76(6): 835-848. http://dx.doi.org/10.1016/j.techfore.2008.10.004

Ghazinoory, S.; Ghazinoori, S. 2006. Developing government strategies for strengthening national system of innovation, using SWOT analysis: the case of Iran, Science and Public Policy 33: 529-549. http://dx.doi.org/10.3152/147154306781778759

Ghazinoory, S.; Ghazinouri, R. 2009. Nanotechnology and sociopolitical modernity in developing countries; case study of Iran, Technological and Economic Development of Economy 15(3): 395-417. http://dx.doi.org/10.3846/1392-8619.2009.15.395-417 
Ghazinoory, S.; Heydari, E. 2008. Four scenarios of how nanotechnology will impact Iran's society, IEEE Technology \& Society (Winter), 37-44.

Ghazinoory, S.; Mirzaei, S.; Ghazinoori, S. 2009a. A model for national planning under new roles of government, case study: national initiative for nanotechnology in Iran (NINI), Science and Public Policy 36(3): 241-249. http://dx.doi.org/10.3152/030234209X427095

Jamali, D.; Yianni, M.; Abdallah, H. 2011.Strategic partnerships, social capital and innovation: accounting for social alliance innovation, Business Ethics: a European Review 20: 375-391. http://dx.doi.org/10.1111/j.1467-8608.2011.01621.x

Kaasa, A. 2009. Effects of different dimensions of social capital on innovative activity: evidence from Europe at the regional level, Technovation 29:218-233. http://dx.doi.org/10.1016/j.technovation.2008.01.003

Kaplan, R. S.; Norton, D. 1992. The balanced scorecard: measure that drive performance, Harvard Business Review (January-February), 71-79.

Kaplan, R. S.; Norton, D. 2001. The Strategy-focused Organization. Harvard Business School Press, Boston.

Kaplan, R. S.; Norton, D. P. 2004. Strategy Maps: Onverting Intangible Assets Into Tangible Outcomes. Harvard Business School Press, Boston.

Keshavjee, K.; Manji, A.; Singh, B.; Pairaudeau, N. 2009. Failure of electronic medical records in Canada: a failure of policy or a failure of technology?, Stud. Health. Technol. Inform. 143: 107-114.

Lundvall, B. A. 1992. National System of Innovation Towards a Theory of Innovation and Interactive Learning. Printer, London.

Mikalsen, K. H. 2003. Balanced Scorecard as a Strategic Management Tool: the Case of Seagull as. Masters Thesis in Information and Communication Technology University College Grimstad.

Molina-Morales, F. X.; Martínez-Fernández, M. T. 2010. Social networks: effects of social capital on firm innovation, Journal of Small Business Management 48: 258-279.

http://dx.doi.org/10.1111/j.1540-627X.2010.00294.x

OECD.1999. Managing National Innovation Systems. OECD, Paris.

Putnam, R. 2000. Bowling Alone: the Revival of American Community. New York, Simon Schuster.

Rigby, D.; Bilodeau, B. 2007. Management Tools and Trends 2007. A Survey from Bain and Company. Available from Internet: http://www.bain.com/management_tools/Management_Tools_and_Trends_2007.pdf

Sheetz, T.; Vidal, J.; Pearson, T. D.; Lozano, K. 2005. Nanotechnology: awareness and societal concerns, Technological Forecasting \& Social Change 27: 329-345.

Soofi, A.; Ghazinoory, S. 2011. The network of the Iranian techno-economic system, Technological Forecasting and Social Change 78: 591-609. http://dx.doi.org/10.1016/j.techfore.2010.11.005

The World Bank Group. 1999. Social Capital for Development, What is Social Capital?

Watts, J.; Segal, L. 2009. Market failure, policy failure and other distortions in chronic disease markets, BMC Health Services Research 9(1): 102. http://dx.doi.org/10.1186/1472-6963-9-102

Whitman, J. 2007. The governance of nanotechnology, Science and Public Policy 34(4): 273-283. http://dx.doi.org/10.3152/030234207X215551

Sepehr GHAZINOORY is an associate professor in the Department of Information Technology Management, Tarbiat Modares University, Tehran, Iran. He received his BSc, MSc and PhD in Industrial Engineering from Iran University of Science and Technology (IUST). He has authored numerous books and articles about cleaner production, strategic planning and management of technology in Persian and English. He was also a consultant to the Iran presidential Technology Co-operation Office (TCO) for four years and senior consultant in formulating the Iran Nanotechnology National Initiative. He is currently a consultant to different ministries and organizations. 
Abdol SOOFI is a professor in the Department of Economics, University of Wisconsin-Platteville, University Plaza, Platteville, Wisconsin, USA. He received his PhD degree from the Department of Economics, University of California, Riverside. He was a Visiting Scholar at the School of Business Administration, University of Wisconsin-Milwaukee, from September 1998 until August 2001. He also was a Visiting Scholar at the Institute of Mathematics and Systems Sciences, Chinese Academy of Sciences, Beijing, China, in summer of 2002, and a Visiting Scholar at School of Management, Harbin Institute of Technology, Harbin, China in August 2005, and August-September 2007. Moreover, Dr Soofi's name is on the Fulbright Senior Specialists list. In addition to publishing over thirty scholarly articles in various learned journals in the fields of economics and international finance, input-output modeling, economic doctrinal history, nonlinear deterministic dynamics and economics, Dr Soofi has published a book on international business, and co-edited a book Modeling and Forecasting Financial Data: Techniques of Nonlinear Dynamics with Dr Linagyue Cao. 